\title{
陸中紫波の屋敷と耕地
}

\section{[山口俩一郎，村田 孝介]}

1. 散村に於ける屋數と耕地 北上川右岸の陸中紫波地方には，奥炣山胍

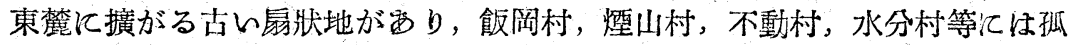
立莊宅が分布してるる。此等の屋敷と耕地との關係には，土地の開拓，村落 の形成，或は祳:業經營上からみて，日本覀村發達上の基礎的問題が，倚若干 - 崩れすれ殘存してるるとみられるので，古い屋敷より新しい屋敷へ，本家よ り分策へとをがめてみるととにする。

屋敷と耕地との關係は, 散居とその生活, 特に東北の如き高緯度冷凉な地 jの扇狀地開拓の氣候, 地形, 地味等との關係を觀察し, 我及の跙が，如何 に刻苦して開拓居住したかを丁䁇に調べるべきである。

ての地亏の屋敷は概狋所有耕地の中央或は上手位置し，規模は宏壯で， 特沉舊家とい注れる大本家の屋敷面積は一町步前後を占め。その中にワセダ 或㹥ウチダと呼ぶ水田，苗代，荣園，果樹園を含み，屋敷の西北を圍むエグ ネは面積だけでも一段步以上あり，だかも一屋敷林をなしてるるのが西 る。かく屋敷內の土地のみでも獨立の農業經營が可能である所謂礐業桱營適 性規模面積に相當するのは注目すべざある。これが辰業經營の基地である と言ふ觀念は强く，本家は旸論か」る屋敷をつくり，ての形態を維持せんと する傳統が强い。

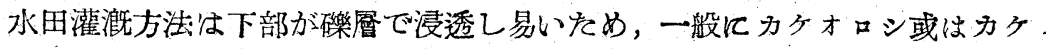
ナガシでする。特にての甚しいものをカラ田と呼ぶが，カラはカラッコ等と も言ひ，砂利土で周圍より高く，烟，草地等に殘されてるる。 
カケナガシ々水利と水溫調筑に苦勞がいるので, 開拓過程, 農㭌作業の便 利汃らも，屋敷を水利の便な水系の分水源に選び，耕地を屋敷の周圍或は水

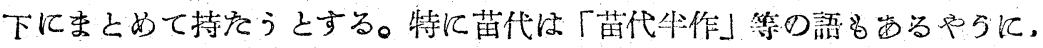
屋敷內に通し苗代にして維持し，分家の耕地の水利が惡けれしば，苗代を本家

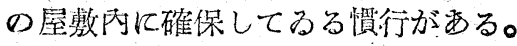

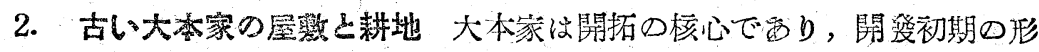

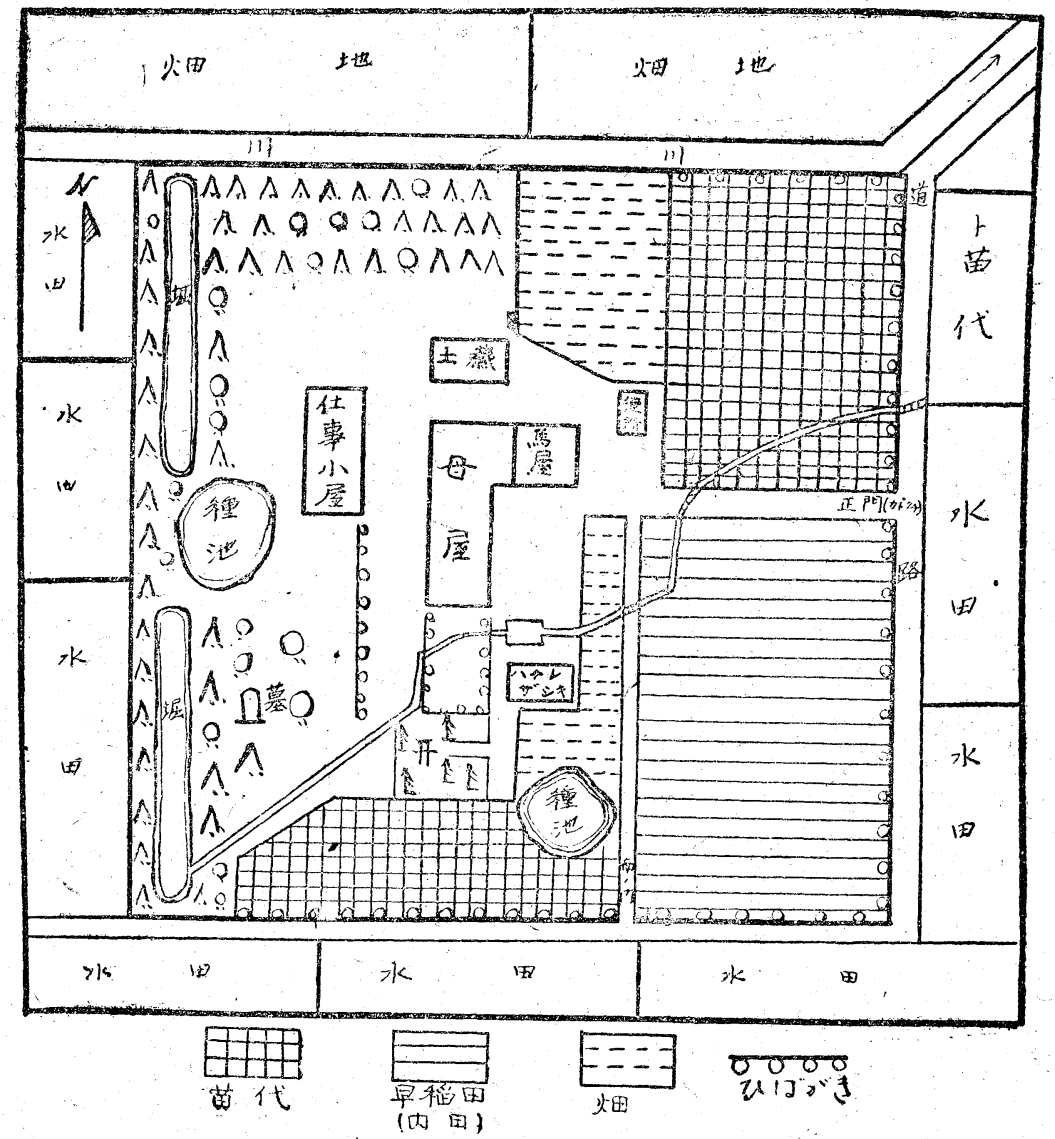

第 1 圖 大本家の屋數之耕地 
態をもらワセダ及び苗代の經營を主とするかにみえる。屋敷は家の表象でお り，長方形或は正方形の廣大な面積內に曲屋，破風造りの大母屋と附屬家 屋, 墓地, 地ノ神, ワセダ，苗代，荣園等の耕地を含认莊宅と言ふにふさは しい。古くはての總へてが宅地と度つてるたが，近年地自變換により耕地と 改め、或はエグネの一部を狹め屋敷面積它縮少しようとする傾向がみえる。

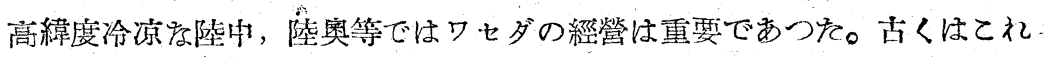
を苗代と共に屋敷內に多ち，屋敷田，或は內田等とも呼んだが，屋敷を縮小

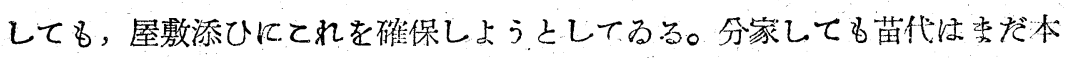
家の屋敷內に殘存するのが目立つ。水分村の久保屋敷で六六分，飯岡村神 田屋敷七户分, 同村高畔屋敷には賽に九户分の苗代がつくられてるる。古く はてれでけの苗代分の耕地を名子等により手作りしてるたるのbあつたと言 ふ。濑次分家に分け，小作を增して經營を縮小しても，苗代だけをかく本家 屋敷に殘してるるのがあるのは本家の農業經營の變化の渦程定物語つてるる とみられる。著明な一，二の例をみると。

\begin{tabular}{|c|c|c|c|}
\hline 1. 久保屋敷 & 紫波郡水分村 & 2. 神田屋數 & 紫波郡飯岡村 \\
\hline 屋數總面積 & 1 町 步 & 屋敷總面積 & 1 町 1 段步 \\
\hline 水 田 & 3 段五畧步 & 水 田 & 3 段 步 \\
\hline 苗 代 & 2 段步(六F分) & 苗 代 & 3 段 5 喃步 七戶分) \\
\hline 烟 & 1 段 步 & 畑 & 1 段 5 畧步 \\
\hline 果樹園 & 5 畧 步 & 果樹園 & 1 段 5 畧步 \\
\hline 坴坼數 & 152 坪 & - 建玶數 & 112 坪 \\
\hline その他 & 2 段 5 賋步 & その他 & 2 段 2 畧步 \\
\hline
\end{tabular}

農:業經營の基礎が屋敷に置かれるから，大本家が破產する場合も，屋敷の 堀を埋め，土手，エグネを取拂ひ，屋敷によつて最低生活を確保しよらとす るどとは，煙山村の大本家木城屋敷等に窥はれる。 
屋敷の周圍にはワセダの外に，前田，後田，南田，北田等の名稱があり， ワツパカ仕事の點から五人役，三人役，收量か、は五十刚，二百刚，或注開 沰者の名をとつて倉之助, 彌五郎等上名づけてるるのが多い。古く大本家は 若者夫婦數組をおいたり，分家，名子等が來て耕作してるた爲に，時ふ二， 三町步にも及ぶ耕地が屋敷をとりまいてみた。古い分家もてのやうな屋敷構

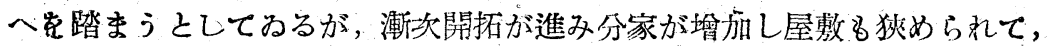
耕地は分割され，苗代，ワセダ等も屋敷外に分散するやうになつてるる。

3. 屋敨面皘の漸減之耕地：分家の際には祖よりうけついだ屋敷周圍の土 地ではなく，賞代の人が開拓したり買求めをものを分けるのが多く，血族，

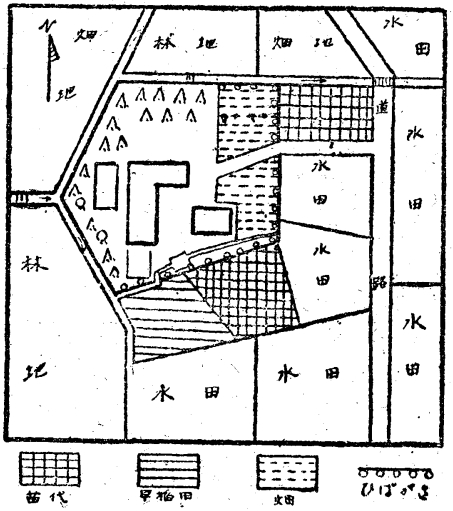

第 2 圖 古い分家の屋數と耕地 名子、ナノリア七等の分家にて異度り， 本家の傳統, 部落の憒行によつても差異 がある。特に屋敷圍りの水利の便な本家 のナラビを分けるととは呼はれて，一般に は屋敷の位置, 耕地多本家程には勝れす。 まとまつそ耕地多得られず，ワセダ，苗 代等を確保すことが困難で，本家の苗 代を小作しをければをらぬ事情も起る。 てれは新しい分家程顯著で，次にその例 をあげてみる。

3. 金重郎堂屋敷 紫波郡不動村 屋數總面積 3 段 步 畑 1 段 步 建 雨 112 玶 その他 1 段 6 䇉步 佮屋數の周園に田 1 町 7 段, 畑 3 段, 苗代门段它自作してるる。

4. 北オギタ屋敷 紫波郡不動村 屋敷總面積 2 段 5 畧步 苗 代 5 畧 步 畑 1 段步 建 玶 80 玶 その他 7 站 步 
これ等は何れも屋敷圍りにワセダ。苗代をもち，屋敷及び耕地の總面積が 大本家の屋敷總面積に酷似してわる。水分村久保屋敷等は古くより分家には 七百盵，郎ち一町步を與へる慣行があつたと言ひ，農家絰營の最小限の面積 が賞てられ，當地方の適性規模面積の概念とるなつてるる。

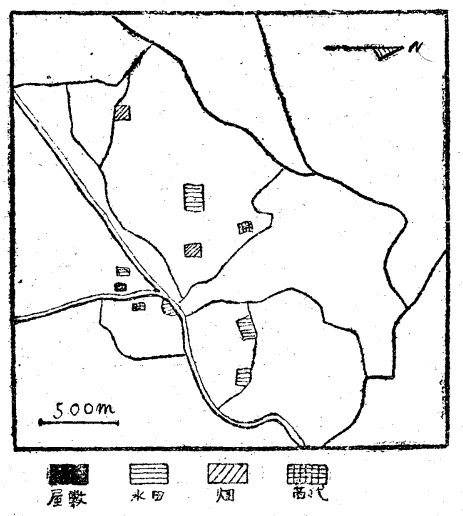

第 3 圖 新しい分家の屋教と耕地 ○見取滴

新分家は屋敷面積は潮減し, 畑地, 荒 地等新墾地が多く，步キ田的ち飛び飛び の耕地所有形態になる。屋敷どりは少な くる本家と 1500 米程度に隔てられて るる。

\section{4. 屋数と耕地の樣式 近年の分家屋} 敷はアラクを起した新しい畑地等が選ば れ, 古い本家位置が奥犲山脈麓古㞛狀地 の末端が北上川氾濫原と接する附近にす 当与のは，分家，孫分家は潮次上手江延 ぴてをり，麓徐頭近い本家よりは下流へ，扇央江位置する本家は四方に分家 分分散さ呕名。

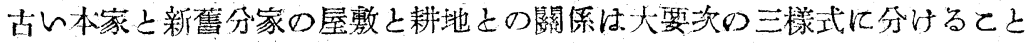
方出来る。

第一は屋敷の中にワ七ダ，內田，苗代等の廣い耕地を持つるので最も古い 本家の型であり，㧓立莊宅として標式的のものである。てれ等がエグネにか

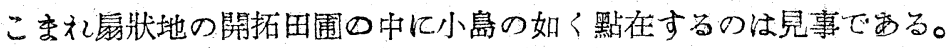

第二はこの地方に最も多い型で，ワセダ，苗代が屋敷ぞ八の外に出るるの で，少なくも明治初年前の古い分家屋敷に多、。

第三は近年の分家にみられるるるので, 屋敷, 耕地, “苗代等が各々遠距離に 分散してる，耕作上不便が多レ。 
この三樣式がぞの程度の比率を方かは，閉拓の時代，土地の性質，地方 の傳統等によつて異孛る。

今煙山村の一例を示せ济，

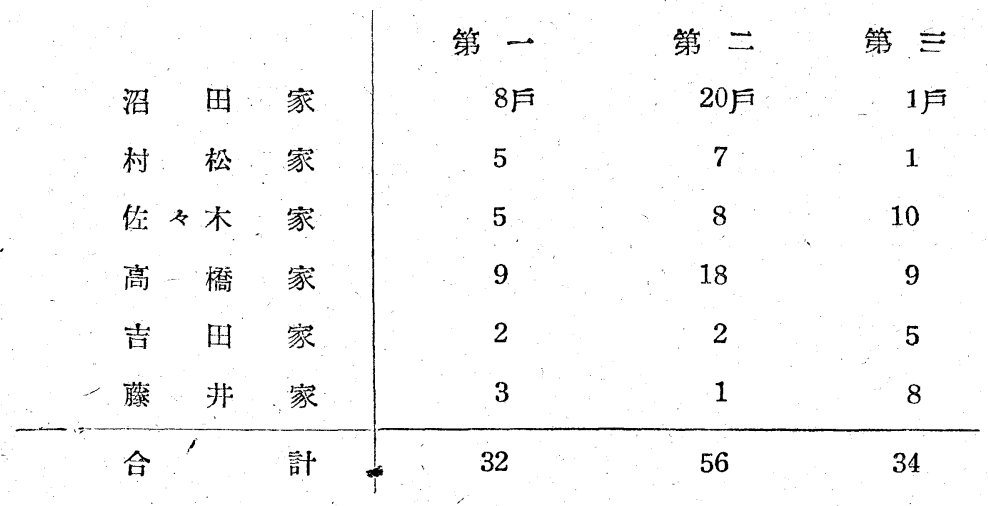

嘗ては最適の地に第一樣式が占居したでめららが，開拓が進み，人口密度 が增して第二樣式が增加し，近年，特に明治以來第三樣式が激增し，散居の 密度崖增し，逐には一部に集村の傾间すらみられるやうになつてるる。 